\title{
Rancang Bangun Sistem Pemotong pada Mesin Pengupas dan Pemotong Kentang Spiral dengan Kapasitas $15 \mathrm{Kg} / \mathrm{Jam}$
}

\author{
Design and Building the Cutting System for The Potato Peeler and Spiral \\ Cutter with a Capacity of $15 \mathrm{Kg} / \mathrm{Hour}$
}

\author{
Syadilla Ega Maharani ${ }^{1 *}$, Joko Setia Pribadi' ${ }^{2}$, Agus Santoso ${ }^{3)}$, Fadillah $^{4)}$, Murni \\ Handayani $^{5)}$ \\ ${ }^{1}$ Mahasiswa Jurusan Teknik Mesin, Politeknik Negeri Cilacap, Jl. Dr. Soetomo No.1 Sidakaya, Cilacap \\ ${ }^{2,3}$ Staf Pengajar Jurusan Teknik Mesin, Politeknik Negeri Cilacap, J1. Dr. Soetomo No.1 Sidakaya, Cilacap \\ ${ }^{4,5}$ Staf Pengajar Program Studi Pengembangan Produk Agroindustri, Politeknik Negeri Cilacap, J1. Dr. Soetomo No.1 Sidakaya, Cilacap \\ * Email korespondensi : syadillamaharani17@gmail.com \\ Dikirim 2021-01-29 \\ Direvisi 2021-04-07 \\ Diterima 2021-04-22
}

\begin{abstract}
Spiral potato peeler and cutter is a machine used to assist the production process of a home-based bussiness in potato processing, starting from the peeling process to the cutting process carried out in one machine frame. The design and construction of the cutting system on spiral potato peeler and cutter machine with a capacity of 15 kg/hour has several objectives, namely being able to make detailed analisis of a spiral potato cutting machine, being able to calculate parts of the machine elements used in parts of the cutting system and being able to did spiral potato machine testing. The methode used in the preparation of this project report is through the VDI 2222 approach which begins with the plan, conceptual, design and completions stages.The results of the calculation of the cutting system elements on the spiral potato peeler and cutter machine include the large diameter of the shaft used is $12,7 \mathrm{~mm}$, the use of 84 watt motor power and the capacity of the cutting system on the spiral potato cutting machine is 15,25 kg/hour.
\end{abstract}

Keywords : Cutters, Spiral Potatoes, VDI 2222

\section{ABSTRAK}

Mesin pengupas dan pemotong kentang spiral adalah mesin yang digunakan untuk membantu proses produksi usaha rumahan dalam pengolahan kentang yang berawal dari proses pengupasan hingga proses pemotongan yang dilakukan dalam dalam satu rangka mesin. Rancang bangun sistem pemotong pada mesin pengupas dan pemotong kentang spiral kapasitas $15 \mathrm{~kg} / \mathrm{jam}$ memiliki beberapa tujuan yaitu membuat perancangan sistem pemotong pada mesin pengupas dan pemotong kentang spiral dengan kapasitas $15 \mathrm{~kg} / \mathrm{jam}$, mampu menghitung bagian-bagian elemen mesin yang digunakan pada bagian sistem pemotong dan mampu melakukan pengujian mesin kentang spiral. Metode yang digunakan dalam proses pengerjaan adalah pendekatan VDI 2222 yang diawali dengan tahap merencana, mengkonsep, merancang dan penyelesaian. Hasil perhitungan elemen mesin sistem pemotong pada mesin pengupas dan pemotong kentang spiral meliputi besar diameter poros yang digunakan yaitu $12,7 \mathrm{~mm}$, penggunaan daya motor 84 watt dan kapasitas sistem pemotong pada mesin pemotong kentang spiral adalah 15,25 $\mathrm{kg} / \mathrm{jam}$.

Kata Kunci : Pemotong, Kentang Spiral, VDI 2222

\section{Pendahuluan}

Kentang (Solanum tuberosun, L) merupakan jenis tanaman sayuran semusim, berumur pendek dan berbentuk perdu atau semak dengan fase hidup berkisar antara 90-180 hari bergantung pada varietasnya. Tanaman kentang umumnya berdaun rimbun dan letak daun berseling-seling mengelilingi batang dengan bentuk daun oval agak bulat dan ujungnya meruncing. Batangnya berbentuk segi empat atau segi lima bergantung pada varietasnya. Sistem perakaran tanaman kentang adalah perakaran tunggang dan serabut. Di antara akar-akar tersebut ada yang akan berubah bentuk dan fungsinya menjadi bakal umbi (stolon) dan selanjutnya menjadi umbi kentang (Samadi, B. 2007)

Kentang juga merupakan tanaman pangan bernilai ekonomi tinggi sebab permintaan pasar terhadap kentang semakin meningkat seiring dengan bertambahnya industri pengolahan makanan berbahan baku kentang untuk membuat berbagai produk olahan kentang dengan jumlah pproduksi yang banyak dan daya saing produk yang dihasilkan. Pada kenyataannya untuk menyiapkan produk olahan 
kentang tidak semudah penyajiannya, karena harus dimulai dengan proses pemotongan kentang menjadi bentuk potongan balok atau stik.

Kentang Kyu adalah sebuah usaha makanan yang berbahan dasar kentang dengan jumlah produksi yang banyak. Usaha tersebut mengolah kentang dari proses pengupasan kentang menjadi spiral dengan bantuan alat pemotong kentang (peeler) hingga proses pemotongan kentang menjadi spiral dengan bantuan alat pemotong kentang spiral yang masih dioperasikan menggunakan tenaga manusia dengan cara menusuk kentang ke batang penancap kentang lalu poros engkol diputar menggunakan tangan. Dengan jumlah produksi makanan yang membutuhkan kentang dengan rata-rata 3-7 kg dalam sehari. Pada industri pengolahan makanan berbahahan baku kentang dengan jumlah produksi yang banyak apabila proses pemotongan dilakukan secara manual akan membutuhkan waktu yang lama dan membutuhkan tenaga kerja yang banyak sehingga efisiensi dalam bekerja pun kurang. Berdasarkan permasalahan yang ada, penulis berinisiatif membuat sebuah alat bantu untuk proses produksi usaha Kentang Kyu yaitu mesin pengupas dan pemotong kentang spiral yang bertujuan untuk memudahkan pengguna untuk menjalankan usaha dan dapat meningkatkan hasil produksinya dibandingkan menggunakan alat pemotong kentang spiral manual. Pada penelitian Mungkur, dkk (2015), merancang alat pengiris kentang bentuk spiral yang bertujuan untuk meningkatkan mutu produksi pengoalahn pascapanen kentang. Alat pengiris kentang spiral memiliki beberapa komponen di antaranya rangka, tuas pemutar, pisau pengiris (panjang $6 \mathrm{~cm}$ dengan lebar pisau 2,8 $\mathrm{cm}$ ), poros (panjang poros 24,2 $\mathrm{cm}$ dengan 2,5 $\mathrm{cm}$ ) dan penahan kentang. Prinsip kerja alat pengiris kentang tersebut diputar dengan tuas pemuar. Setelah alat dipastikan dalam keadaan siap pakai, kentang yang sudah dikupas kulitnya dimasukkan ke dalam alat pengiris yang telah diberi alat penyangga pada bagian tengah kentang terlebih dahulu, kemudian memutar tuasnya. Kentang yang diputar akan teriris berbentuk spiral oleh mata pisau pengiris. Alat ini mampu mengiris rata-rata $1 \mathrm{~kg}$ kentang dalam waktu 376,3 detik atau kapasistas efektif penggunaannya yaitu sebesar 9,54 kg/jam.

Menurut Aldrianto, dkk (2015) merancang sekaligus memodifikasi "mesin pengupas dan pemotong kentang semi otomatis" yang menggabungkan piringan pengupas dan pemotongnya menjadi satu. Mesin ini dapat menghasilkan irisan kentang yang tipis berbentuk keripik kentang. Sugandi (2017), merancang mesin pengiris talas, fungsi utama dari mesin pengiris talas ini adalah membuat talas menjadi bentuk irisan melintang (bulat). Mesin pengiris talas menghasilkan kualitas irisan talas dalam kondisi baik sebesar $80 \%$ dan daya yang dibutuhkan untuk pengirisan sebesar 530 watt. Dalam penelitian ini makan penulis ingin membuat mesin pengupas dan pemotong kentang spiral yang dapat memotong kentang lebih cepat dan pengoperasiannya yang mudah dan lebih efisien dalam segi waktu pengerjaannya.

\section{Metode Penelitian}

Alat dan bahan yang digunakan dalam membuat alat atau mesin merupakan hal yang harus diperhitungkan, karena sangat berpengaruh terhadap hasil dan kualitas alat atau mesin yang dibuat.

Beberapa peralatan yang digunakan dalam proses pengerjaan sistem pemotong pada mesin pengupas dan pemotong kentang spiral antara lain : Laptop, Mesin Gerinda, Mesin Bubut, Mesin Las, Mesin Gurdi, Gerinda tangan 4", Jangka Sorong. Sedangkan beberapa bahan yang digunakan untuk proses pengerjaan sistem pemotong pada mesin pengupas dan pemotong kentang spiral antara lain : Bearing, Tombol, Kabel, Poros transportir, Motor DC, Pisau Pemotong, Plat stainless steel.

Metode perancangan dalam proses rancang bangun sistem pemotong pada mesin pengupas dan pemotong kentang spiral dengan kapasitas $15 \mathrm{~kg} / \mathrm{jam}$ menggunakan metode VDI 2222. Perancangan menggunakan metode VDI 2222 yang sistematis diharapkan dapat mempermudah perancangan untuk menguasai sistem perancangan tanpa harus menguasai secara detail. Metode ini membantu mempermudah proses merancang sebuah produk dan mempermudah proses belajar bagi pemula serta dapatmengoptimalkan produktivitas perancang untuk mencari pemecahan masalah paling optimal (Dharmawan Harsokoesoemo, 2004). Tahapan prosedur perancangan dapat dijabarkan sebagai berikut : 1) Merencana, 2) Mengkonsep, 3) Merancang, 4) Penyelesaian. Proses perancangan tersebut digambarkan dalam diagram alir seperti pada Gambar 1. 


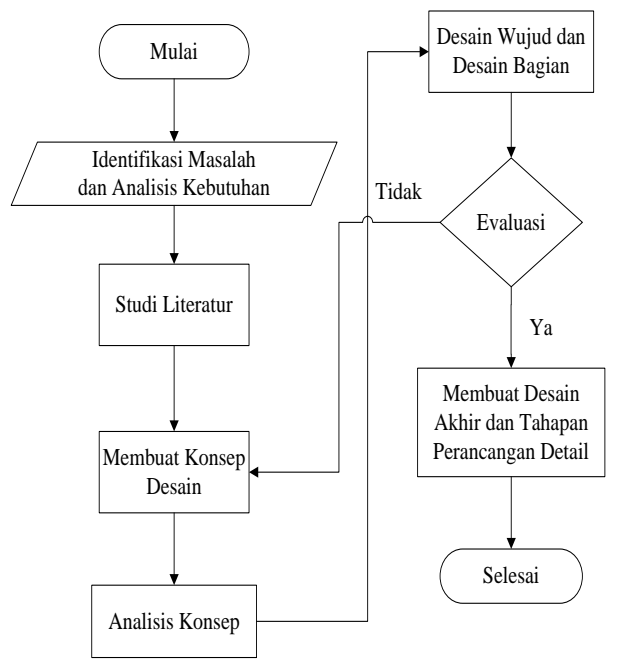

\section{Perhitungan Elemen Mesin}

Gambar 1. Diagram alir VDI 2222 perancangan mesin

Perhitungan elemen mesin meliputi perhitungan daya motor listrik, perhitungan diameter poros. Rumus yang diperuntukkan untuk menghitung daya motor listrik yang dibutuhkan pada sistem pemotong kentang adalah rumus power screw, untuk mencari daya motor listrik yang dibutuhkan dapat menggunakan persamaan :

a. Perhitungan tan sudut helix

$$
\tan \alpha=\frac{p}{\pi d}
$$

keterangan:

$\tan \alpha=\tan$ sudut helix

$p \quad=\operatorname{pitch}(\mathrm{mm})$

$d \quad=$ diameter benda $(\mathrm{mm})$

b. Perhitungan besarnya gaya yang timbul

$\mathrm{F}=\mathrm{W} \times \tan (\alpha+\theta)$

keterangan :

$\mathrm{F}$ = gaya $(\mathrm{N})$

$\mathrm{W}=$ berat yang akan dipindahkan $(\mathrm{kg})$

$\tan \alpha=\tan$ sudut helix

$\tan \theta=\tan$ koefisien gesek

c. Perhitungan torsi motor listrik

$\mathrm{T}=\mathrm{F} \times \mathrm{r}$

keterangan :

$\mathrm{T}=\operatorname{torsi}(\mathrm{N} . \mathrm{m})$

$\mathrm{F}=$ gaya $(\mathrm{N})$

$\mathrm{r}=$ jari-jari poros $(\mathrm{m})$

d. Perhitungan daya motor

$\mathrm{P}=\mathrm{T} \times \omega$

keterangan :

$\mathrm{P}=$ Daya (watt)

$\mathrm{T}=$ Torsi (N.m)

$\omega=$ kecepatan putaran (rpm)

Sedangkan untuk rumus perhitungan poros yang digunakan pada sistem pemotong kentang pada mesin pengupas dan pemotong kentang spiral meliputi persamaan-persamaan sebagai berikut:

a. Perhitungan daya rencana

$P_{\mathrm{d}}=\mathrm{f}_{\mathrm{c}} \times \mathrm{P}$

Keterangan:

$P_{\mathrm{d}}=$ daya rencana 
$\mathrm{f}_{\mathrm{c}}=$ faktor koreksi

$\mathrm{P}=$ daya yang ditransmisikan $(\mathrm{kW})$

b. Perhitungan momen puntir rencana

$\mathrm{T}=9,74 \times 10^{5} \frac{P d}{n_{2}}$

Keterangan :

$\mathrm{T}=$ momen puntir rencana $(\mathrm{kg} \cdot \mathrm{mm})$

$P_{\mathrm{d}}=$ daya rencana $(\mathrm{kW})$

$n_{2}=$ putaran poros (rpm)

c. Menentukan tegangan geser

$\tau_{\mathrm{ijin}}=\frac{\sigma}{S f 1 \times S f 2}$

dimana :

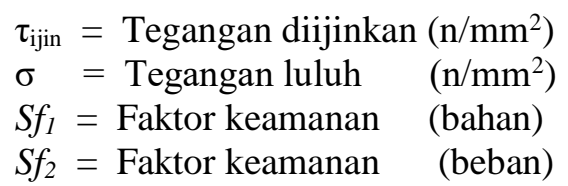

d. Perhitungan diameter poros

Perhitungan diameter poros

$$
d_{s}=\left[\frac{5,1}{\tau_{a}} K_{t} C_{b} \mathrm{~T}\right]^{1 / 3}
$$

dimana :

$d_{s}=$ Diameter poros $(\mathrm{mm})$

$\tau_{a}=$ Tegangan geser $\left(\mathrm{n} / \mathrm{mm}^{2}\right)$

$K t=$ faktor keamanan

$\mathrm{Cb}=$ beban lentur

$\mathrm{T}=$ momen rencana

2.4 Prosedur Proses Produksi

Prosedur proses produksi merupakan langkah atau tahapan dalam suatu proses pengerjaan yang dilakukan dengan beberapa proses yaitu pemotongan, pembubutan, gerinda, gurdi,pengelasan, finishing dan perakitan. Prosedur proses produksi sistem pemotong pada mesin pengupas dan pemotong kentang spiral ditunjukkan dalam Gambar 2.

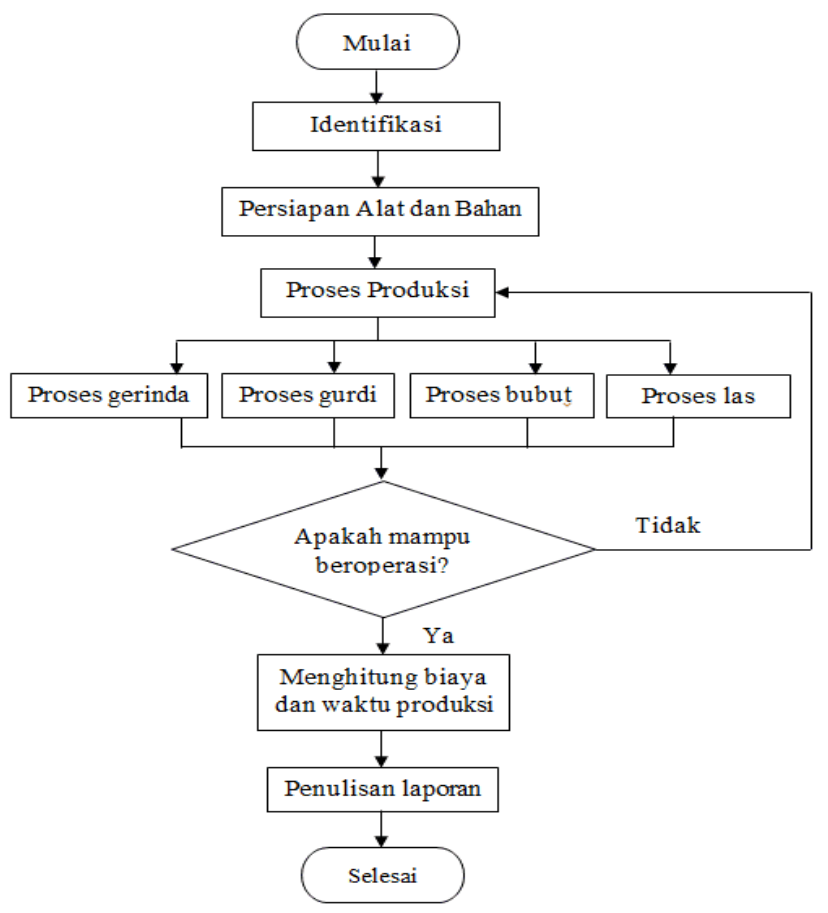

Gambar 2. Diagram alir proses produksi 


\subsection{Metode Uji Fungsi}

Langkah-langkah proses pengujian fungsi mesin digambarkan pada diagram alir sebagaimana ditunjukkan pada Gambar 3.

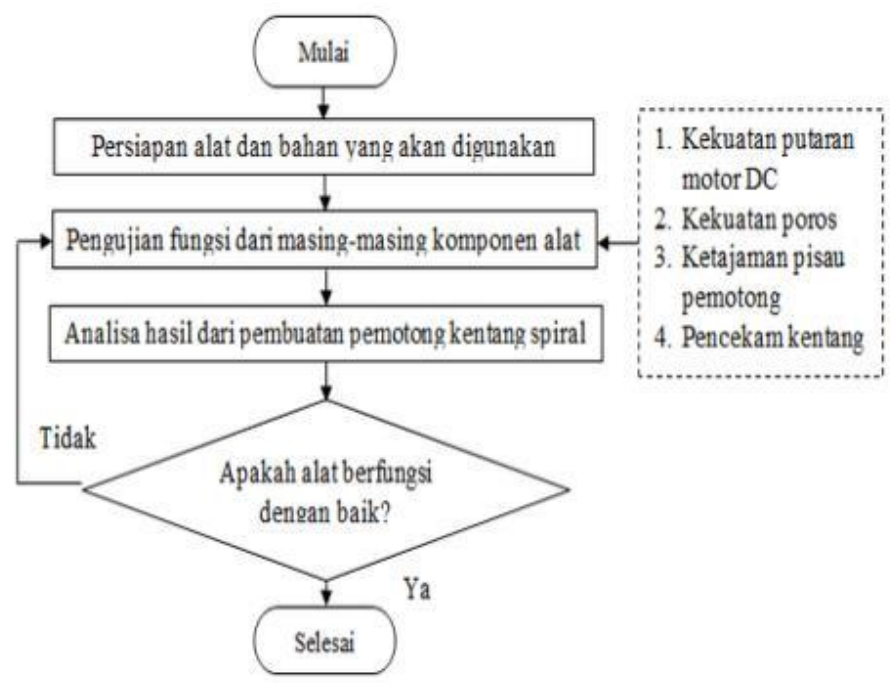

\section{Hasil dan Pembahasan}

Gambar 3 Diagram alir uji fungsi

\subsection{Perancangan}

Perancangan sistem pemotong pada mesin pemotong dan pengupas kentang spiral meliputi beberapa tahap antara lain merencana, mengkonsep, merancang, dan penyelesaian.

a. Merencana

Penulis merancang alat ini dimaksudkan untuk meningkatkan proses produksi dalam suatu pekerjaan khususnya pemotongan kentang yang akan dibentuk menjadi kentang spiral. Mesin pemotong kentang spiral ini sangat dibutuhkan untuk mengurangi biaya maupun estimasi waktu produkstivitas dalam pemotongan kentang spiral. Dari latar belakang tersebut, selanjutnya penulis menyusun kebutuhan konsumen terhadap sistem poemotong pada mesin pengupas dan pemotong kentang spiral sebagai berikut :

1. Mudah dioperasikan

2. Tidak membahayakan operator

3. Perawatan mudah

4. Hemat energi

5. Material tahan karat

b. Mengkonsep

Dalam menentukan pilihan konsep yang akan digunakan akan lebih mudah menggunakan sistem nilai. Dari penilaian akan timbul rangking dari konsep yang terbaik.

c. Merancang

Proses setelah semua konsep ditemukan adalah konsep disatukan dan dirancang.

Desain wujud mesin pegupas dan pemotong kentang spiral sangat dibutuhkan untuk mengurangi biaya maupun estimasi waktu produktivitas dalam pemotongan dengan bentuk spiral. Desain wujud ditunjukkan dalam Gambar 4.

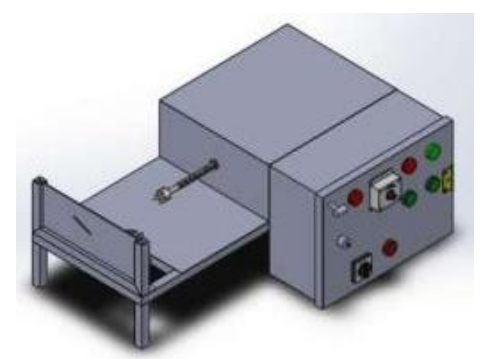

Gambar 4. Desain wujud mesin pengupas dan pemotong kentang spiral 


\subsection{Perhitungan Elemen Mesin}

Perhitungan elemen mesin dilakukan untuk mengetahui ukuran maupun kemampuan suatu komponen dalam menerima gaya maupun momen yang bekerja. Perhitungan elemen mesin yang dilakukan pada sistem pemotong pada mesin pengupas dan pemotong kentang spiral antara lain menghitung daya motor listrik minimal yang digunakan adalah sebesar 0,197 watt ini diperoleh dari perhitungan tan sudut helix, kemudian perhitungan gaya yang timbul, dan perhitungan torsi. Poros yang digunakan pada sistem pemotong adalah poros beban puntir. Perhitungan diameter poros yang diizinkan adalah 1,3 $\mathrm{mm}$ sehingga poros yang digunakan berdiameter $12,7 \mathrm{~mm}$ dikarenakan untuk memperkuat kekuatan poros.

\subsection{Proses Produksi}

Proses produksi merupakan kelanjutan dari proses perancangan, proses perhitungan elemen mesin. Di dalam proses produksi meliputi kegiatan rencana operasi, perhitungan waktu proses produksi. Lama waktu yang dibutuhkan dalam setiap proses berbeda-beda dalam setiap prosesnya. Sistem pemotong pada mesin pemotong dan pengupas kentang spiral (Gambar 5) pada proses pemotongan memerlukan waktu 67,96 menit, proses gurdi memerlukan waktu 32,096 menit, proses bubut memerlukan waktu 48,8 menit, sedangkan proses las memerlukan waktu kurang lebih 10 menit.

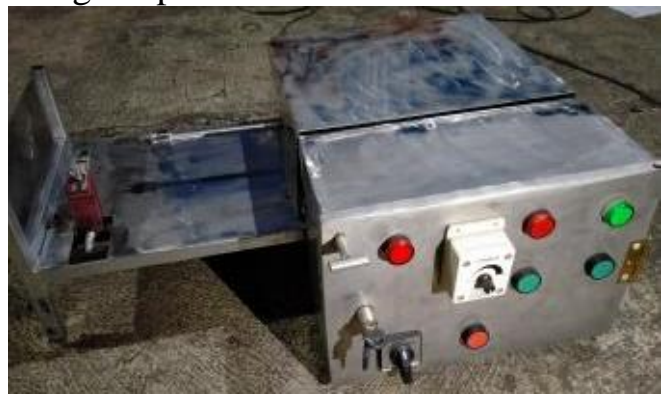

3.4 Pengujian fungsi mesin

Gambar 5. Pengerjaan Mesin Pengupas dan Pemotong Kentang Spiral

Pengujian fungsi mesin bertujuan untuk mengetahui apakah mesin tersebut dapat memotong kentang spiral dengan tebal $2 \mathrm{~mm}$, sehingga dapat digunakan dalam proses produksi dan untuk mengetahui kekurangannya, sehingga ke depan data yang diperoleh dapat dipakai sebagai acuan untuk membuat mesin yang lebih baik lagi. Berikut merupakan form chek sheet uji fungsi mesin pemotong kentang spiral bagian pemotong Tabel 1 sedangkan form check sheet proses uji hasil mesin pengupas dan pemotong kentang spiral bagian pemotong dapat dilihat pada Tabel 2.

Tabel 1. Form chek sheet uji fungsi bagian pemotong

\begin{tabular}{|c|l|c|c|}
\hline \multirow{2}{*}{ No } & \multicolumn{1}{|c|}{ Part Name } & \multicolumn{2}{|c|}{ Function } \\
\cline { 3 - 4 } & & $\boldsymbol{G}$ & NG \\
\hline 1. & Mesin & $\sqrt{ }$ & \\
\hline 2. & Kelistrikan & $\sqrt{ }$ & \\
\hline 3. & - Motor DC (Power window) & $\sqrt{ }$ & \\
& - Bearing linear & $\sqrt{ }$ & \\
\hline 4. & - Poros transportir & $\sqrt{ }$ & \\
& - Pencengkam kentang &
\end{tabular}

\subsection{Perhitungan kapasitas waktu dan hasil produksi mesin}

Setelah dilakukan pengujian mesin dapat membuat potongan spiral tebal $2 \mathrm{~mm}$ dengan hasil yang seragam sehingga yang dapat digunakan untuk proses produksi. Untuk dapat mengetahui kapasitas waktu dan hasil produksi mesin pada bagian pemotong maka dilakukan suatu pengujian hasil. Pada pengujian ini dilakukan dengan satu kali proses pemotongan dengan waktu \pm 20 detik pada mesin. Hasil pengujian mesin pengupas dan pemotong kentang spiral disajikan dalam Gambar 6. 
Tabel 2 Form check sheet proses uji hasil bagian pemotong mesin

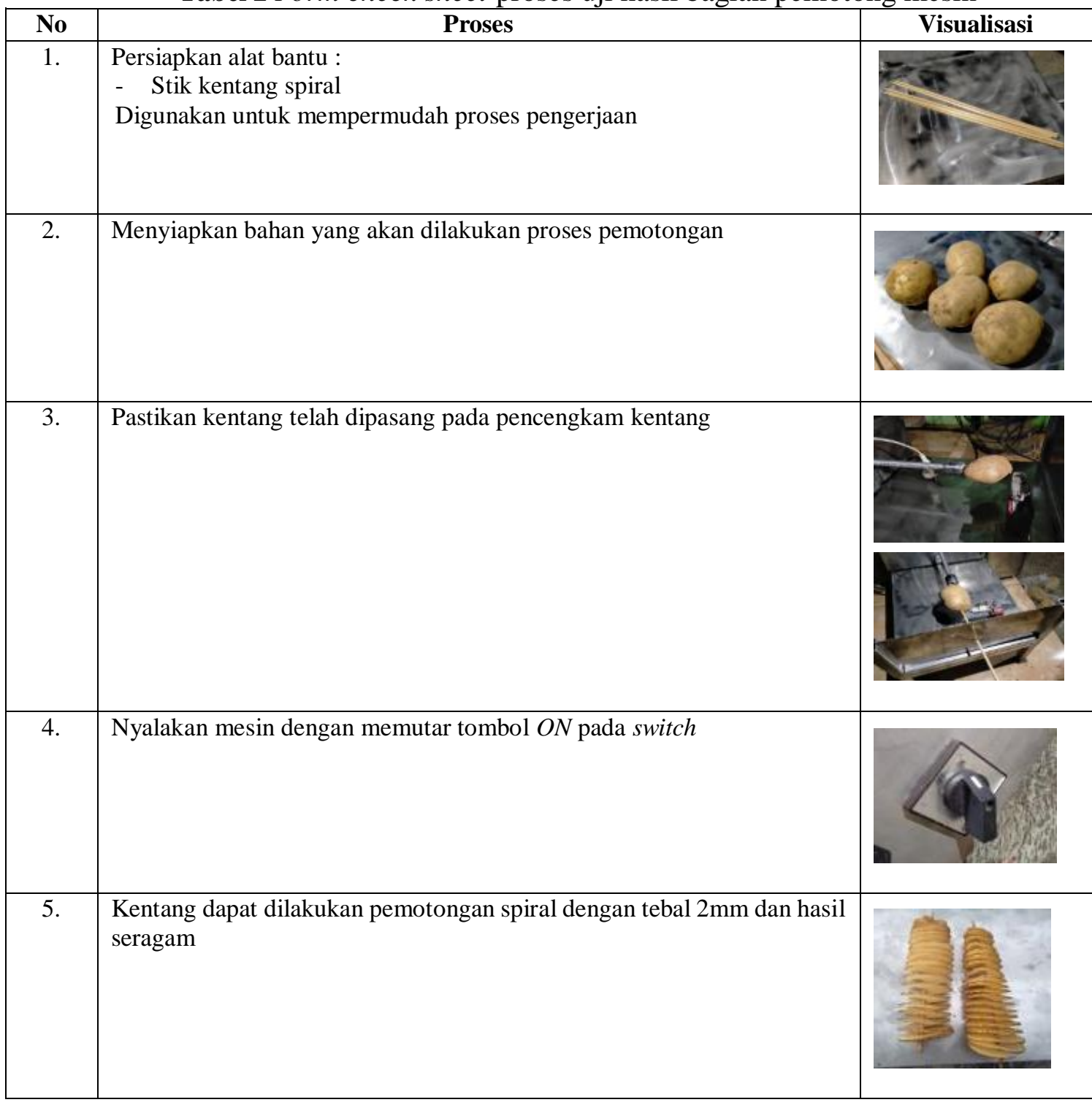

Keterangan : $G=G O O D$ (berfungsi) $\quad N G=N O G O O D$ (tidak berfungsi)

\section{Hasil pengujian kentang spiral}

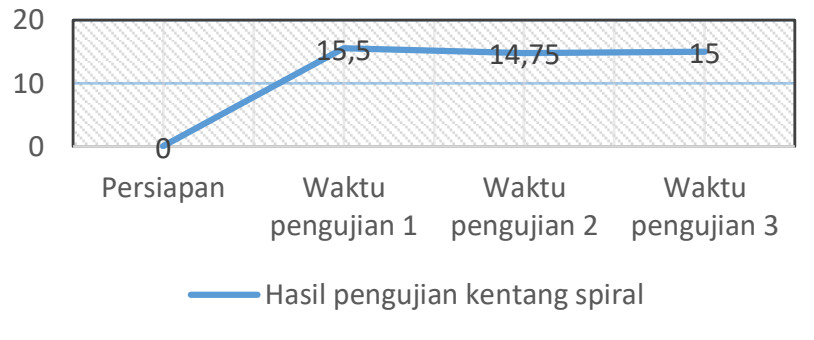

Gambar 6. Diagram hasil pengujian kentang spiral

Jumlah hasil pengujian jam ke 1, 2, $3=\frac{\text { jumlah hasil 1,2,3 }}{3}$

$$
\begin{aligned}
& =\frac{15,5+14,75+15}{3} \\
& =15,25 \mathrm{~kg} / \mathrm{Jam}
\end{aligned}
$$


Berdasarkan jumlah hasil pengujian hasil kapasitas yang diperoleh dalam satu jam bervariatif karena ukuran dari panjang, diameter dan jenis kentang berpengaruh pada saat proses pemotongan menjadi spiral. Maka dari itu, penulis melakukan 3 kali pengujian dengan durasi 1 jam tiap pengujiannya dan diperoleh hasil rata-rata yaitu $15,25 \mathrm{~kg} / \mathrm{jam}$.

\section{Kesimpulan}

Dalam proses rancang bangun sistem pemotong pada mesin pengupas dan pemotong kentang spiral pada bagian ini, didapat suatu kesimpulan sebagai berikut:

1. Rancang bangun sistem pemotong pada mesin pengupas dan pemotong kentang spiral memudahkan pengguna untuk menjalankan usaha dan dapat meningkatkan hasil produksinya dibandingkan menggunakan alat pemotong kentang spiral manual.

2. Hasil perhitungan bagian-bagian elemen mesin :

a. Daya motor digunakan 84 watt

b. Diameter poros transportir yang digunakan untu sistem pemotong yaitu $12,7 \mathrm{~mm}$

3. Uji hasil mesin proses pemotong pada mesin pemotong kentang spiral dengan kecepatan $80 \mathrm{rpm}$ dalam 1 jam yaitu sebanyak $15,52 \mathrm{~kg}$ kentang

\section{Ucapan Terima Kasih}

Terima kasih kepada seluruh dosen, plp, dan juga teman-teman pada Jurusan Teknik Mesin, Politeknik Negeri Cilacap atas bimbingan, bantuan, semangat yang diberikan kepada penulis sehingga penulis dapat menyelesaikan keseluruhan tahapan dalam proses pengerjaan sistem pemotong pada mesin pengupas dan pemotong kentang spiral ini sehingga mesin dapat dioperasikan dengan baik.

\section{Daftar Pustaka}

Aldrianto, A. dan Sakti, A.M. (2015). Mesin Pengupas dan Pemotong Kentang Semi Otomatis. Jurnal Rekayasa Mesin, 3(1), 69-75

Harsokoesoemo, D. (2004). Pengantar Perancangan Teknik (Perancangan Produk). Institut Teknologi Bandung. Bandung

Mungkur, ILJ., Rohanah, A., dan Panggabean, S. (2017). Rancang Bangun Alat Pengiris kentang Bentuk Spiral (Design of Spiral Potato Slicer Equipment). Jurnal Rekayasa Pangan dan Pertanian, 5 (1), 188-191

Samadi, B. (2007). Kentang dan Analisis Usaha Tani. Kanisius. Yogyakarya

Sugandi, W.K., Yusuf, A., dan Thoriq, A. (2017). Rancang Bangun Mesin Pengiris Talas. Jurnal Teknik Pertanian Lampung, 6(1), 53-62 